\title{
PENGARUH LAMA PEREBUSAN KULIT TELUR PADA PEMBUATAN BUBUK SUPLEMEN KALSIUM
}

\author{
Effect Of Eye Of Seed Leather Deeping In The Powder Of Calcium Supplement Powder. \\ Rafika Dwi Puspitasari dan Muhammad Aniar Hari Swasono \\ Program Studi Ilmu dan Teknologi Pangan, Fakultas Pertanian, Universitas Yudharta Pasuruan \\ Email : fikadwi282@gmail.com
}

\begin{abstract}
Eggs are foods that are widely consumed in Indonesia. Not only for consumption of eggs are also used in the production process of various kinds of bread and cakes, it makes the level of waste from the egg shell is increasing. With the utilization of waste in the form of egg shells into food products can reduce the amount of waste in the egg-based industry. This study examines the percentage of boiling duration of egg shell powder aims to determine the level of calcium. The method used is non factorial Single Random Design. There are 5 treatments and each treatment is repeated 3 times. Data analysis using ANOVA method if there is influence continued with 5\% BNT test to find the real difference between substitution of eggshell powder. Observations include calcium levels and organoleptic tests of taste, color and aroma. Based on the result of research, the average value of calcium powder of egg shell obtained is 131,451,16. The lowest levels of calcium were obtained in the T0 treatment powder (without boiling), while the highest calcium content was obtained on T4 treatment bubbles with a boiling duration of 60 min. Result of calculation of effectiveness index showed the best treatment combination on TO (without boiling) that is taste with value 3,25\%, aroma withvalue 3,3\%,colorwithvalue 3,75\%.
\end{abstract}

Keywords: Egg Skin, Boiling Time, Calcium

\begin{abstract}
ABSTRAK
Telur merupakan makanan yang banyak di konsumsi di indonesia. Bukan hanya untuk konsumsi telur juga di gunakan dalam proses produksi berbagai macam roti dan kue, itu menjadikan tingkat limbah dari kulit telur semakin meningkat. Dengan adanya upaya pemanfaatan limbah berupa kulit telur menjadi produk pangan dapat mengurangi jumlah limbah pada industry berbahan baku telur. Penelitian ini meneliti tentang prosentase lama perebusan bubuk kulit telur bertujuan untuk mengetahui kadar kalsium. Metode yang digunakan yaitu Rancangan Acak Tunggal non factorial. Terdapat 5 perlakuan dan masing-masing perlakuan diulang 3 kali. Analisis data menggunakan metode ANOVA apabila ada pengaruh dilanjutkan dengan uji BNT 5\% untuk mencari beda nyata antara substitusi bubuk cangkang telur. Pengamatan yang dilakukan meliputi uji kadar kalsium dan uji organoleptik rasa, warna dan aroma. Berdasarkan hasil penelitian, nilai rata-rata kadar kalsium bubuk kulit telur diperoleh 131.451,16. Kadar kalsium terendah diperoleh pada bubuk perlakuan T0 (Tanpa perebusan), sedangkan kadar kalsium tertinggi diperoleh pada bubbuk perlakuan T4 dengan lama perebusan 60 menit. Hasil perhitungan indeks efektifitas menunjukkan kombinasi perlakuan terbaik pada pada T0 (Tanpa perebusan) yaitu rasa dengan nilai 3,25\%, aroma dengan nilai 3,3\%, warna dengan nilai $3,75 \%$.
\end{abstract}

Kata kunci : Kulit Telur, lama perebusan, kalsium 


\section{PENDAHULUAN}

Telur merupakan makanan yang banyak di konsumsi di indonesia. Bukan hanya untuk konsumsi telur juga di gunakan dalam proses produksi berbagai macam roti dan kue, itu menjadikan tingkat limbah dari kulit telur semakin meningkat. Oleh karena itu, perlu memanfaatkan limbah dari kulit telur ini menjadi bubuk kulit telur yang banyak mengandung kalsium dan bisa menurunkan tingkat pembuangan limbah di indonesia. Dan bubuk kulit telur ini bisa dikonsumsi dari segala kalangan dari anakanak sampai dewasa bahkan tua.

Menurut Direktorat Jendral Peternakan Dan Kesehatan Hewan (20122016), produksi telur di Indonesia dari tahun ketahun semakin meningkat dan pada tahun 2016 mencapai 162.051.262 ton. Kandungan gizi kulit telur yang tidak kalah dengan kandungan telurnya tersebut dapat di manfaatkan sebagai sumber suplemen kalsium bagi kesehatan masyarakat di Indonesia.

Kandungan gizi kulit telur yang tak kalah tinggi dari telurnya, saat ini belum mendapat perhatian. Para pakar kimiawi telah melakukan uji coba terhadap cangkang telur, sehingga kandungan dari cangkang telur telah terbukti. Bahwa cangkang telur telah tersusun oleh bahan anorganik 95,1\%, protein 3,3\% dan air 1,6\%. Komposisi kimia dari kulit telur terdiri dari protein $1,71 \%$, lemak $0,36 \%$, air $0,93 \%$, serat kasar $16,21 \%$, abu 71,34\% (Nursiam, 2011).

Berdasarkan hasil penelitian sebelumnya oleh Miles, serbuk kulit telur ayam mengandung kalsium sebesar 401 7,2 gram atau sekitar $39 \%$ kalsium, dalam bentuk kalsium karbonat. Terdapat pula strontium sebesar 372161 gram, zat-zat beracun seperti $\mathrm{Pb}, \mathrm{Al}, \mathrm{Cd}$, dan $\mathrm{Hg}$ terdapat dalam jumlah kecil, begitu pula dengan $\mathrm{V}$, $\mathrm{B}, \mathrm{Zn}, \mathrm{P}, \mathrm{Mg}, \mathrm{N}, \mathrm{F}, \mathrm{Se}, \mathrm{Cu}$, dan Cr (Garry dan Richard, 2009).

Kulit telur kering mengandung sekitar 95\% kalsium karbonat dengan berat 5,5 gram (Butcher dan Miles, 1990). Sementara menurut Hunton dan Garry (2009) melaporkan bahwa kulit telur terdiri atas 97\% kalsium karbonat. Selain itu, rerata dari kulit telur mengandung 3\% fosfor dan 3\% terdiri atas manesium, natrium, kalium, seng, manga, besi dan tembaga. (Butcher dan Miles, 1990).

Kalsium merupakan zat gizi yang kurang diperhatikan oleh masyarakat indonesia dalam pemenuhan kebutuhan harianya. Asupan kalsium untuk masyarakat indonesia masih rendah. Data yang berasal dari Departemen Kesehatan RI tahun 2002 menunjukkan bahwa asupan rata-rata kalsium orang indonesia hanya $254 \mathrm{mg} /$ hari. Padahal massa tulang yang dibentuk secara optimal di usia anak-anak dan remaja akan menjadi senjata ampuh untuk mencegah osteoporosis (Sulaiman M, 2009). Kekhawatiran akan kurang memadainya masukan kalsium melalui bahan pangan dapat diatasi dengan upaya penambahan kalsium pada pangan (Dongoran N, 2007).

Dengan adanya upaya pemanfaatan limbah berupa kulit telur menjadi produk pangan dapat mengurangi jumlah limbah pada industri berbahan baku telur. Hal ini merupakan salah satu kelebihan dari kulit telur, dan kekurangan kulit telur adalah adanya broadcast yaitu bintik-bintik kecoklatan yang terdapat di kulit telur dan mengandung bakteri Streptococcus, dimana bakteri tersebut bisa menembus kulit dan masuk kedalamnya. Faktanya, bintik-bintik kecoklatan di kulit telur adalah hal yang normal. Bintik-bintik dikulit adalah hasil dari pembuluh darah disaluran reproduksi ayam yang pecah selama proses pebentukan telur (Jansen Ongko, 2017)

\section{METODOLOGI PENELITIAN}

\section{Bahan dan alat}

Bahan yang digunakan adalah bubuk cangkang telur. Bahan uji kalsium adalah sampel cangkang telur, asam nitrat $6 \mathrm{~m}$, akuades, dan padatan $\mathrm{C}_{\mathrm{a}} \mathrm{Cl}_{2} \cdot 2 \mathrm{H}_{2} \mathrm{O}$. Alat yang digunakan adalah neraca analitik, kaca aroji, gelas kimia $100 \mathrm{ml}$, corong, labu ukur $100 \mathrm{ml}$, pipet tetes, gelas ukur $5 \mathrm{ml} 10 \mathrm{ml} 50$ 
$\mathrm{ml}$, baang pengaduk, blender, oven, hot plate, object glass, krus porselen, spektrofotometer serapan atom.

\section{Prosedur Penelitian}

\section{Pembuatan Bubuk Cangkang Telur}

Penelitian ini terdiri atas penelitian pendahuluan dan penelitian utama. Penelitian pendahuluan terdiri dari dua tahap. Tahap pertama yaitu pembuatan bubuk kulit telur dan tahap kedua penentuan faktor lama perebusan kulit telur. Penelitian utamanya adalah analisis kadar kalsium dari bubuk kulit telur dan uji organoleptik bubuk kulit telur. Pembuatan bubuk cangkang telur dilakukan dengan menggunakan metode Wahyuni N, (2005).

Pada pembuatan bubuk cangkang telur sebagai bahan dasar substitusi adalah kulit telur. Kulit telur dihasilkan dari toko roti Gendis Bakery. Setelah cangkang telur dikumpulkan kemudian dicuci sampai bersih dan direndam selama 1 jam. Setelah dicuci bersih kemudian cangkang telur direbus. Pastikan cangkang tenggelam dalam air rebusan. Rebus cangkang dalam air mendidih, ini berguna untuk membunuh bakteri salmonella pada cangkang telur. Ada 4 kali perlakuan dalam perebusan cangkang telur, yaitu 20 menit, 30 menit, 40 mnenit dan 60 menit dan tanpa perebusan. Selanjutnya setelah perebusan yaitu penirisan agar air sisa perebusan semua terjatuh. Dan selanjutnya yaitu pengeringan. Cangkang telur yang sudah direbus kemudian dikeringkan dengan cara dipanggang dalam loyang tertutup selama kurang lebih 5 menit pada suhu 140 derajat celcius dan pastikan cangkang benar-benar kering dan tidak mengandung air. Setelah cangkang benar-benar kering tahap selanjunya yaitu penggilingan. Letakkan cangkang yang kering pada tempat penggilingan. Pastikan semua cangkang dapat tergiling halus agar bubuk cangkang yang dihasilkan bisa dicampur dengan makanan lain. Setelah cangkang menjadi bubuk. Simpan bubuk dalam toples tertutup agar terjaga dari bakteri dan air.

\section{Uji Kadar Kalsium}

Dalam analisa kadar kalsium pada cangkang telur adalah dengan menyiapkan sampel bubuk kulit telur $\left(\mathrm{C}_{\mathrm{a}} \mathrm{CO}_{3}\right)$. Kemudian dilanjutkan dengan pembuatan larutan sampel $\mathrm{C}_{\mathrm{a}} \mathrm{NO}_{3}$, dengan cara bubuk kulit telur ditimbang sebanyak 1 gram dengan neraca analitik dan di masukkan kedalam Erlenmeyer dan di tambahkan 20 $\mathrm{ml}$ asam nitrat. Kemudian di panaskan di atas hot plate pada suhu $113 \mathrm{C}$ hingga semua bubuk cangkang telur larut, lalu di dinginkan. Larutan kemudian di saring dengan menggunakan kertas saring dan dituangkan kedalam labu ukur $100 \mathrm{ml}$ dan di tambahkan aquades sampai tanda batas.

Pembuatan larutan induk Ca 100 ppm, yaitu dengan menimbang 0,3675 $\mathrm{g}$ $\mathrm{C}_{\mathrm{a}} \mathrm{Cl}_{2} \cdot 2 \mathrm{H}_{2} \mathrm{O}$ dan dimasukkankedalam gelas kimia $250 \mathrm{ml}$, dan ditambahkan 20ml akuades dan diaduk. Larutan kemudin di masukkan kedalam labu ukur $250 \mathrm{ml}$ dan ditambahkan akuades sampai tanda batas dan dikocok sampai larutan homogen.

Pembuatan larutan $\mathrm{Ca}$; Dibuat larutan standar $\mathrm{Ca} \quad 1,2,4,6,8,10$ ppm. Cara pembuatan larutan $1 \mathrm{ppm}$, yaitu diambil 1 $\mathrm{ml}$ larutan standar $\mathrm{Ca} 100 \mathrm{ppm}$ dan dimasukkan kedalam labu ukur $100 \mathrm{ml}$, kemudian ditambahkan akuades sampai tanda batas. Pembuatan larutan 2 ppm, yaitu diambil $2 \mathrm{ml}$ larutan standar Ca 100 ppm dan diamasukkan kedalam labu ukur $100 \mathrm{ml}$ kemudian ditambahkan akuades sampai tanda batas. Pembuatan larutan 4 ppm, yaitu diambil 4 ml larutan standar Ca 100 ppm dan di masukkan kedalam labu ukur $100 \mathrm{ml}$, kemudian ditambahkan akuaes sapai tanda batas. Pembuatan larutan $6 \mathrm{ppm}$, yaitu diambil $6 \mathrm{ml}$ larutan standar Ca 100 ppm dan dimasukkan kedalam labu ukur $100 \mathrm{ml}$, kemudian ditambahkan akuades sampai tanda batas. Pembuatan larutan 8 ppm, yaitu diambil 8ml larutan standar Ca 100 ppm dan dimasukan kedalam labu ukur $100 \mathrm{ml}$, kemudian ditambahkan akuades sampai tanda batas. Pembuatan larutan $10 \mathrm{ppm}$, yaitu diambil $10 \mathrm{ml}$ larutan standar $\mathrm{Ca} 100$ ppm dan dimasukkan kedalam labu ukur 
$100 \mathrm{ml}$, kemudian ditambahkan akuades sampai tanda batas.

Analisis dengan Spetrofotometer Serapan Atom (SSA). Dengan cara larutan standar dan larutan sampel kemudian dianalisis dengan SSA dengan menggunakan panjang gelombang 422,7 nm. Setelah itu dicatat nilai absorbansi, dibuat kurva standart $\mathrm{Ca}$ dan ditentukan persamaan regresi linearnya. Kemudian diplotkan absorbansi sampel dengan kurva standar Ca.

Rancangan percobaan dalam peneltian ini adalah dengan menggunakan rancangan acak tunggal. Dengan faktor tanpa perebusan dan lama perebusan 20 menit, 30 menit, 40menit, dan 60 menit pada produk dengan 3 kali ulangan

\section{Prosedur Uji Sifat Organoleptik}

Dalam uji sifat organoleptik diperlukan 20 penelis. Adapun penelis yang digunakan adalah penelis agak terlatih, terdiri dari mahasiswa Teknologi PanganUniversitasYudharta Pasuruan yang telah mendapat latihan uji organoleptic, uji tersebut meliputi warna, rasa dan aroma.

\section{Analisa Data}

Data yang diperoleh dari pengukuran kadar kalsium, dianalisa menggunakan metode Anova (Analisis Of Varians) rancangan acak tunggal, apabila ada pengaruh dilanjutkan dengan uji BNT 5\% untuk mencari beda nyata antara substitusi bubuk cangkang telur.

Setelah formulir uji hedonic diisi, dilakukan pengolahan data yaitu skoring, pada uji kesukaan yang akan digunakan adalah $5=$ sangatsuka, $4=$ suka, $3=$ agaksuka, 2= tidaksuka, $1=$ sangat tidak suka.Untuk mengetahui adanya pengaruh substitusi tepung kulit singkong dengan lama perebusan 20,30, 40, dan 60 menit perebusan terhadap tingkat kesukaan konsumen dilakukan pengujian statistik friedman.

\section{HASIL DAN PEMBAHASAN}

\section{Analisa Kadar Kalsium}

Berdasarkan hasil penelitian, nilai rata-rata kadar kalsium bubuk kullit telur diperoleh 131.451,16 (Tabel 1). Kadar kalsium yang dihasilkan berkisar antara 355061,82 - 432007,83. Nilai ini berada dalam kisaran nilai kadar kalsium yang ditetapkan SNI untuk tepung, tepung kasar dari udang-udangan dan tepung kulit, yaitu 0306.19.00.00 layak untuk dikonsumsi manusia. Berdasarkan hasil ANOVA yag dilakukan terhadap kadar kalsium menunjukkan bahwa. Lama perebusan memberikan pengaruh yang nyata terhadap kadar kalsium.

Tabel 1 Kadar kalsium bubuk kulit telur dengan faktor lama perebusan

\begin{tabular}{cc}
\hline Perlakuan & Kadar kalsium \\
\hline T0 & 118353,94 \\
T1 & 125322,30 \\
T2 & 129337,85 \\
T3 & 140239,09 \\
T4 & 144002,61 \\
\hline
\end{tabular}

Keterangan : T0( tanpa perebusan), T1 (20 menit perebusan), T2 (30 menit perebusan) T3 (40 menit perebusan) dan T4 (60 menit perebusan).

Hasil analisis menunjukkan bahwa frekuensi perebusan berpengaruh nyata terhadap kadar kalsium. Semakin lama perebusan kulit telur maka semakin meningkat kadar kalsium. Peningkatan ini disebabkan oleh jenis kalsium pada tepung cangkang telur adalah kalsium karbonat. Kalsium yang berasal dari hewan seperti kalsium karbonat akan menjadi susah larut dalam cairan ketika berada dalam suhu $25^{\circ} \mathrm{C}$. Memungkinkan itu yang menyebabkan semakin lama perebusan jadi semakin meningkat kadar kalsium yang dihasilkan. Kadar kalsium yang tinggi pada bubuk kulit telur tidak semuanya dapat diserap oleh tubuh. Hal ini disebabkan oleh bioavailabilitas kalisum pada bubuk kulit telur ini masih belum diketahui. Cangkang 
telur mengandung kalsium karbonat yang memiliki bioavailabilitas kira-kira sebesar kurang lebih $40 \%$. Bioavailabilitas $40 \%$ ini termasuk kategori baik.

\section{Analisa Organoleptik}

\section{Rasa}

Pengujian rasa terhadap bubuk kulit telur pada penelitian ini dimaksudkan untuk mengetahui kesukaan terhadap perubahan rasa akibat faktor lama perebusan. Prosentase penerimaan penelis pada kesukaan rasa berkisar antara 1,75\% 2,35\%. Pada Gambar 2 menunjukkan bahwa tigkat kesukaan penelis tertinggi terdapat pada kode sampel T0 yaitu tanpa perebusan, yaitu karena sampel tanpa perebusan tidak menimbulkan bau yang menyegat dan hampir tanpa bau itu yang menyebabkan meningkatnya tingkat kesukaan penelis.

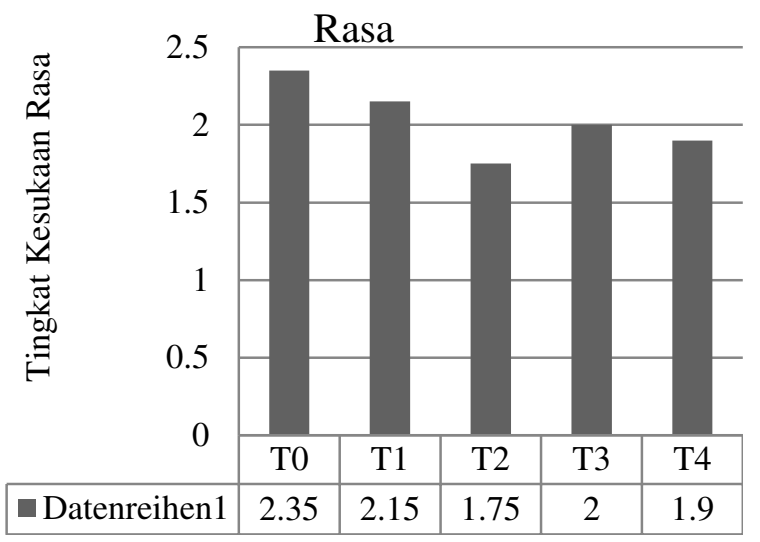

Gambar 2. Tingkat kesukaan penelis terhadap rasa bubuk kulit telur.

Hasil uji statistik dengan menggunakan uji friedman menunjukkan bahwa faktor lama perebusan bubuk kulit telur tidak berbeda nyata. Hal ini berarti bahwa bubuk kulit telur dengan faktor lama perebusan menghasilkan daya trima terhadap rasa tidak diterima oleh konsumen sehingga penelis masih sulit membuat produk bubuk kulit telur yang bisa diterima oleh konsumen.

\section{Warna}

Prosentase penerimaan penelis terhadap warna bubuk kulit telur berkisar antara 2,35\%-2,55\%. Gambar 3 menunjukkan bahwa nilai tertinggi terdapat pada perlakuan lama perebusan 30 menit (T2) dengan nilai 2,55\%. Hal ini menunjukkan kesukaan penelis terhadap warna bubuk kulit telur dengan perlakuan 30 menit perebusan (T2) tersebut lebih disukai penelis yang warnanya terlihat lebih pas tidak pucat dan tidak terlalu tajam inilah yang menaikkan tingkat kesukaan penelis terhadap warna bubuk kulit telur.

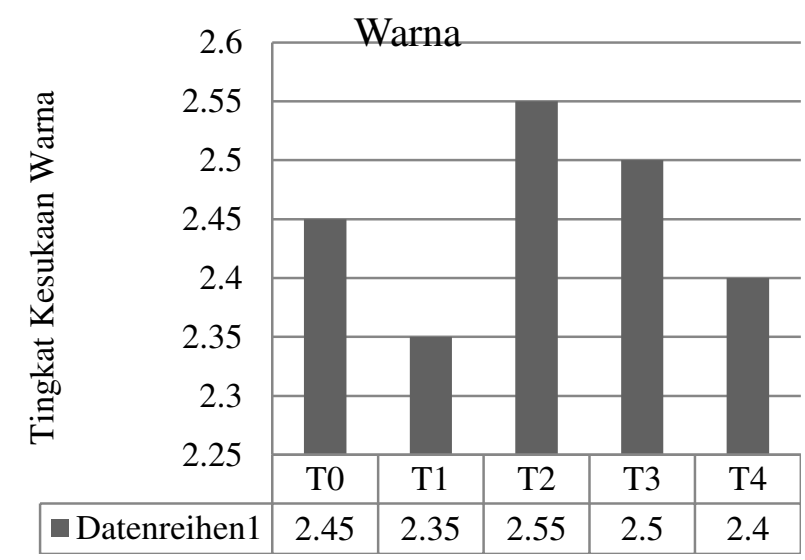

Gambar 3. Tingkat kesukaan penelis terhadap warna bubuk kulit telur

Hasil uji statistik dengan menggunakan uji friedman menunjukkan bahwa faktor lama perebusan terhadap warna bubuk kulit telur tidak berbeda nyata. Hal ini terjadi karena warna bubuk kulit telur tidak terlalu berbeda untuk setiap perlakuan. Warna tidak terlalu berbeda antar perlakuan ini tidak diterima oleh konsumen dalam penelitian ini.

\section{Aroma}

Prosentase penerimaan penelis terhadap aroma bubuk kulit telur dengan perlakuan berkisar 2,35\%-2,7\%. Pada Gambar 4 menunjukkan bahwa nilai tertinggi terdapat pada perlakuan tanpa perebusan (T0). Hal ini dikarenakan perlakuan tersebut lebih disukai penelis karena aromanya yang tidak terlalu tajam bahkan sampai tidak ada aroma sama sekali. 


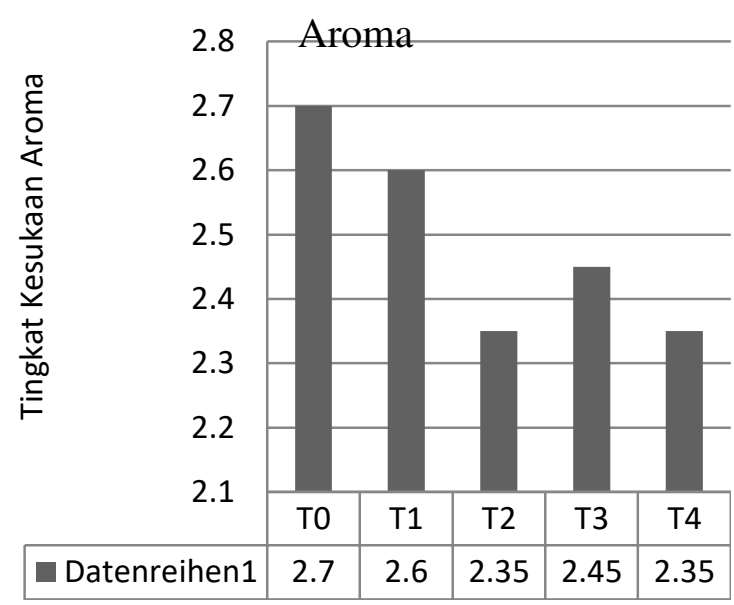

Gambar 4 Tingkat kesukaan penelis terhadap aroma bubuk kulit telur

\section{Perlakuan Terbaik}

Berdasarkan analisis terhadap nilai produk dapat dilihat pada Gambar 5 bubuk kulit telur T0 (tanpa perebusan) terpilih sebagai perlakuan bubuk kulit telur terbaik untuk semua parameter (rasa, aroma, warna). Hal ini didukung oleh penerimaan penelis yang cukup baik terhadap warna, rasa, dan aroma. Selain itu, berdasarkan analisis kalsium, kandungan kalsium dari bubuk kulit telur pada perlakuan tersebut lebih tinggi dibandingkan perlakuan lainya (rasa, aroma, warna). Hal ini menunjukkan bahwa produk bubuk kulit telur sebagai suplemen kalsium ini cukup memberikan gambaran bahwa secara umum produk ini akan bisa ditrima oleh konsumen.

Meskipun konsumen lebih menyukai produk bubuk kulit telur karena kandungan kalsiumnya yang tinggi. Produk ini masih memiliki beberapa kelemahan yang harus diperbaiki. Kelemahan tersebut adalah Rasa yang masih menyengat dan anyir oleh karena itu penelis lebih menyukai produk sampel (T0) yang hampir tanpa rasa padahal kalsium tertinggi terdapat pada sampel (T4). Hal ini dapat dtutupi dengan cara konsumsi bubuk kulit telur dicampur dengan makanan lain atau bisa dikemas dalam bentuk kapsul jadi konsumen bisa langsung mengkonsumsinya tanpa merasakan rasa, warna dan aroma dari bubuk kulit telur, sehingga konsumen bisa mendapatkan sumber kalsium yang dibutuhkan dari bubuk suplemen kulit telur tersebut.

\section{Perlakuan Terbaik}

- Rasa Aroma Warna

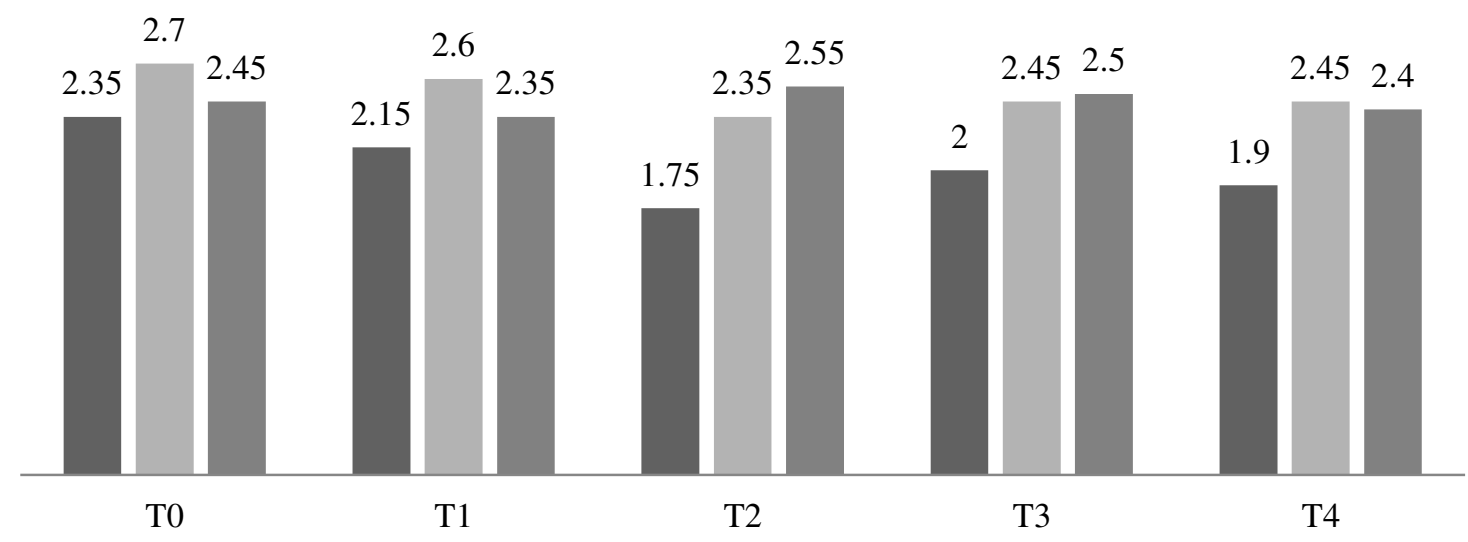

Gambar 6 Tingkat Kesukaan Perlakuan Terbaik Penelis Pada Rasa, Aroma, Warna 


\section{KESIMPULAN DAN SARAN}

\section{Kesimpulan}

Berdasarkan hasil penelitian, nilai rata-rata kadar kalsium bubuk kulit telur diperoleh 131.451,16. Kadar kalsium terendah diperoleh pada bubuk perlakuan T0 (Tanpa perebusan), sedangkan kadar kalsium tertinggi diperoleh pada bubbuk perlakuan T4 dengan lama perebusan 60 menit. Berdasarkan hasil ANOVA yang dilakukan terhadap kadar kalsium menunjukkan bahwa. Lama perebusan memberikan pengaruh yang nyata terhadap kadar kalsium.

Uji kesukaan penelis terhadap rasa aroma dan warna menunjukkan perbedaan pada setiap sampel. Pada rasa kesukaan penelis menunjukkan angka tertinggi pada perlakuan T0 (Tanpa perebusan) yakni $3,25 \%$. Dan untuk warna angka tertinggi pada perlakuan T0 (Tanpa perebusan) yakni $3,75 \%$. Dan untuk aroma angka tertinggi pada perlakuan T1 (20 menit perebusan) yakni $3,15 \%$.

Hasil perhitungan indeks efektifitas menunjukkan kombinasi perlakuan terbaik pada pada T0 (Tanpa perebusan) yaitu rasa dengan nilai $3,25 \%$, aroma dengan nilai $3,3 \%$, warna dengan nilai $3,75 \%$.

\section{Saran}

1. Perlu dilakukan penelitian lebih lanjut dengan faktor lama perebusan di atas 60 menit.

2. Perlu dilakukan penelitian lebih lanjut bubuk cangkang telur dengan penambahan produk lain seperti dalam makanan atau minuman.

3. Perlu dilakukan penelitian lebih lanjut untuk menghilangkan rasa dan aroma yang menyengat dari bubuk kulit telur agar dapat disukai konsumen.

\section{DAFTAR PUSTAKA}

Butcher dan Miles. (1990). Ilmu gizi. Gramedia : Jakarta
Butcher, G.D. dan Miles R. (1990). Concepts of Eggshell Quality. (online). (http://edis.ifas.ufl.edu/pdffiles/VM/V M1300.PDF 1990. [6 desember 2012].

De Garmo ED, Sullivan WG, Canada JR. (1984). Enginering Economy. New York: MacMillan Publishing Company.

Departemen Gizi dan Kesehatan Masyarakat FKM UI, (2007). Gizi dan Kesehatan Masyarakat. PT Raja Grafindo Persada, Jakarta.

Dongoran N., Lilik K., Sri AM. (2007). Pembuatan Susu Kedelai Berkalsium Tinggi dengan Penambahan Tepung Tulang Ikan Kakap Merah (Lutjanus sanguienus). Media Gizi dan Keluarga.

Direktorat Jendral Peternakan dan Kesehatan Hewan, (2012-2016). Proyek Peningkatan Produksi Telur di Indonesia. Direktur Jendral Peternakan Departemen Pertanian: Jakarta.

Gary D, Butcher DVM dan Richard Miles. (2009). Ilmu unggas, Jasa Ektensi Koperasi, Lembaga Ilmu Pangan dan Pertanian Universitas Florida. Gainesville.

James E. Hunton. (2005). Accounting Information System 6 th Editin. Thomson South Western, Ohio.

Kartika B. Pedoman Uji Inderawi Bahan Pangan. (1988). PAU Pangan dan Gizi UGM. Yogyakarta

Nursiam, I. (2011). Uji Kualitas Telur. (Online). Tersedia: http//intannursiam. wordpress.com/2011/02/26/ujikualitas-telur. (15 desember 2012)

Rivera, (1999). The Effect of Micronutrient Deficiencies on Child Growth : A Review of Result From Community Based Supplementation Trials.

Sulaiman M. Double Vitamin D and Calcium for Dislocated. (2009). 
(Online).

http://mardalinasulaiman.blogspot.co $\underline{\mathrm{m} / 20090801 \text { archive.htm. }}$

Stadelman MJ, Cotterill OJ. (1995). Egg Scince and Technology. Connecticut: The AVI Publishing Inc.
Winarno, F.G. (2004). Kimia pangan Dan Gizi. Gramedia Pustaka Utama. Jakarta 